\title{
RELATIONSHIP OF KIBOR WITH BANKING SECTOR IN PAKISTAN
}

\section{LYBASHAHEEN, SANA RIAZ \& MUHAMMAD AHMAD SHAHID}

University of Central Punjab, India

\begin{abstract}
The objective of this research is to study the impact of changes KIBOR on the profitability of banks operating in Pakistan and analyzing the financial condition of five major banks for the period 2002 to 2011. Changes in interest rates discourage automatically saving and investment on the one hand, and raises concerns about the effectiveness of the bank lending channel of monetary policy on the other. Variables were considered, on the basis of previous studies on articles and research papers. In the model, I chose interest rates; loans and advances balance with other banks, loans to financial institutions and investment as independent variables. Regression model was tested to examine the fluctuations in interest rates that have significant impact on the profitability of banks, and expected outcome would be that there is a significant effect of changes in interest rates on bank profitability.
\end{abstract}

KEYWORDS: KIBOR, Banks, Banks Specific Variables \& Profitability

Received: Nov 23, 2017; Accepted: Dec 13, 2017; Published: Jan 06, 2018; Paper Id.: IJAFMRFEB20181

\section{INTRODUCTION}

Financial institutions are the main part of the financial system and play an important role in the economic growth of years, which help investors to invest and get returns and include your strength and energy to the system. It is very important to study the determinants and reliability, internal and external to the profitability of banks in Pakistan. The purpose of this paper is to study thoroughly the data on the internal and external determinants of bank profitability and to examine the thesis of factoring level that make significant impact on bank profitability (Bukhari \& Qudous, 2012).

With current forty-one scheduled banks, seven development finance institutions (DFIs) and five microfinance banks (MFBs) are in service in Pakistan, while their actions are regulated and supervised by the State Bank of Pakistan (SBP). Currently, twenty-nine working groups and commercial banks in Pakistan, including five Islamic banks are fully functional. Along with conventional banks, public sector banks account for four and twenty are representing private sector banks. (Rahman, jan, Iqbal, \& Ali, 2012) Many functions are performed by commercial banks. They play a major role in improving the dynamic capacity of the economy by mobilizing the savings of the people. For the formation of credit, commercial bank accepts deposits but offer services to their customers by opening other accounts. For customer attraction, banks offer interest on their deposits.

All banks are offering all kinds of services, for example by providing different types of loans like cash loans, bank overdraft, ATM cards, Running Finance, fixed deposits, profit and loss account savings, funds transfer, car loans and home financing services, so banks often profit from lending money. There are different parameters which we can assess the financial performance of banks. The banks' performance can be checked through the analysis of different indicators such as total assets, total assets, compared to the benefit of the banks. The return 
indicates the financial performance of banks. The banks having high rate of profit are being made healthy.

The benefit is a fundamental requirement of banking organization with aggressive and least expensive resources of the fund. It is necessary to observe not only as a result, but also a necessity for success in banks increasing competition in financial markets. These data are important, due jointly to the current focus on the issue of the relevant bank's profitability, which affects the success of banks and competence to monitor their portfolio as assets and liabilities, in order to achieve profitability and to identify areas where there may be space as possible to increase the profitability of the bank. Bank assets are divided into two categories - productive assets and non productive assets. Productive assets are those in which the bank earns interest income and non-productive assets are those used for the purpose of reserve requirements and capital to run the day to day operational activities. In this research, I focused on earning assets. This includes balances with other banks, loans to financial institutions, investments in securities and loans and advances. All the assets mentioned are the major resource of income for the bank. Therefore, it is evident that the average income by servicing these assets has a significant influence on the profitability of banks.

Banks are more sensitive to changes in interest rates than most other institutions. The result of changes in interest rates on bank profitability has been a major problem for the banking system. It has been argued that bank hedge interest rate risk may be the most important problem in the economy and the participation of investment crises.

Profitability of banks in Pakistan is reducing over the last few years. The decline may have been caused by many factors such as interest rate, investment, loan and advances. The impact of each of above is not known, and it may continue to affect the profitability of banks in Pakistan.

The general objective of this study is to determine the bank's profitability in Pakistan. As in Pakistan, no comprehensive study has been carried out for the measurement of banks' profitability to show the banking sector performance under changed scenarios, so this study was conducted to realize this need. The specific objectives of the study is to analyze the impact of interest rate, investments, deposits, loans and advances on banking profitability

\section{LITERATURE REVIEW}

Game begins in the literature, as the sum of a variety of concepts in the literature profitability of the bank which shall include, among others, the basic concepts and profitability ratios, and then with the theoretical determinants of banking, industry and specific macroeconomic indicators of bank profitability.

Bukhari and Qudous (2012), according to their research, the main object was to find out the relationship between factors whether they are internal or external, which effect on banking profitability. To find out the results, they used regression model in their methodology and they used panel data of eleven banks from 2005 to 2009 on quarterly basis. The factors considered are the size of the Bank advances (loans), deposits (liability), excluding interest, credit risk, interest income, management fees, the reduced rate, imports, exports and the CPI. They concluded that some internal variables have a significant influence on the profitability of a bank while external variables do not affect the profitability of banks.

Khan, Anuar, Choo, and Khan (2011) worked on to find out the determinants of profitability of banks in Pakistan for this purpose they used the specific bank dependent and independent variables. They took the data of 16 banks' over the period 2000 to 2010. This article uses a fixed effects model and random effects model to examine the impact of the net interest margin, earnings ratio of, bank size, loan growth, interest-free gain, overhead, taxes, loans initiated operating 
expenses, non-performing loans, return on assets and the ratio of deposits ratio. The observed results explain a strong involvement between specific variables and bank profitability. Therefore, non-performing loans are seriously reducing the profitability of banks in small banks.

Rahman, jan, Iqbal, and Ali (2012) studied to examine the main factors of the profitability of conventional and Islamic banks and study the association between the banks' internal personality and performance in Pakistan. Their study analyzes the effect of banks and micro meter settings on conventional and Islamic banks profitability of Pakistan for the period 2006-2010. Results were found in the variables of the model used having a robust effect on the profitability of total assets and more, and cannot be positively related to the Beneficiary higher. As the assets of the bank and there may be network increase inefficiency in the management of the banking sector.

Akhtar, Ali, and Sadaqat (2011) they investigated the impact of how the bank-specific determinants of profitability affect the presentation of Islamic banks. For this they used the sample that is composed of Islamic banks of Pakistan from period 2006 to 2009 and they used ordinary least square method. They concluded that profitability of Islamic banks has a long-term relationship with the size of the bank, the debt ratio, asset management, the ratio of nonperforming loans, the ratio of capital adequacy and operational efficiency, as all these variables affected the profitability.

Kutsienyo (May 2011) worked on to find out the factors of banks profitability in Ghana. He took panel data of 26 commercial banks in Ghana was analyzed over a period of 2000-2009, using a universal least squares method to estimation fixed effect regression models. He took two dependant variables Return on Assets and Return on Equity and other factors, which were incorporated in the regression models were capital adequacy, operating expenses, liquidity, asset quality and size of banks. In addition, macroeconomic determinants and determinants of financial structure captured in the regression models including inflation, gross domestic product (GDP), money supply and the concentration of the banking industry. The model results indicate that ROA capital adequacy; liquidity and bank size is positively significant to the profitability of banks, while asset quality and operating costs are significantly negatively the profitability of banks. In addition, inflation and GDP are positively significant to the profitability of banks, while the provision of money and banking concentration were significantly negative to the profitability of banks.

Asghar, Mushtaq, and Mirza (MARCH 2012) studied the factors of profitability of leasing companies in Pakistan during the period 2006 to 2008 . They used ordinary least squares (OLS) and logistic model (logit) models for the evaluation results. It was established that the size, the net investment in the lease and liquidity have a positive relationship with the profitability of leasing, while leverage and age have a negative relationship with the profitability of leasing companies.

For Azam \& Siddiqui (2012), the purpose of this study was to analyze and compare the profitability of domestic (Public and private banks) and foreign companies operating in the banking market in Pakistan connecting 2004 and 2010, on a quarterly basis. Total of 36 commercial banks in the Pakistani industry represented was in their sample. Further, they divided the sample into three categories: (a) national banks with government control, (b) the Canadian banks with private control, and (c) foreign banks. They applied regression model in their study. They concluded, domestic and foreign banks have different factors of profitability and foreign banks are less affected by macro-economic factors of the host country than domestic banks and they have a higher profit margin in Pakistan.

Abbas, Tahir, and Rehman (2012) they studied on to check out the performance of the commercial banks working 
in Pakistan from the period of 2007 to 2011. For this purpose, they took the date of five scheduled banks. They took the independent variables, Return on Operating Fixed Assets (ROFA) and other factors Total Assets, Total Equity and Total Operating Fixed Assets, and they concluded that variables do have significant impact on commercial banking performance in Pakistan.

Saklain (May 2012) investigated the factors of profitability of private commercial banks in Bangladesh in recent years. He used annual data for all 30 private commercial banks in Bangladesh in 2009 and 2010. He used Multiple regression analyzes for each year to capture important determinants of profitability. He concluded that asset size and NIM (Net Interest Margin) ratio does not have significant effect on the profitability. But, the impact of non-participation in income on profitability has been observed as the most important among different variables, and he also suggested that diversified banking actions counting the investment actions make these banks more profitable.

Zeitun (March 2012) examines factors influencing (foreign ownership, bank specific variables and macroeconomic factors) Islamic banks and conventional Gulf Cooperation Council (GCC) countries. He took the sample of 13 Islamic banks and he took the variables Cost-to-Income, ROE, Size of Bank, Banking Development, Banking Age, Foreign Ownership, Inflation and GDP as independent variables, and he concluded that GDP is positively correlated with banking profitability and Inflation, and Cost-to-Income have negative significance correlated with banking profitability. Furthermore, bank's age and banking development have no significant impact on bank profitability. Foreign Ownership does not improve Islamic and conventional banks' profitability.

Kouser and Saba(2012) in their research used CAMEL method to find out the financial and managerial performance of the Islamic and Conventional banks working in Pakistan. They used SPSS for panel data analysis. And, they concluded that Islamic banks have sufficient capital and good asset quality compared to Islamic branches of conventional banks and conventional banks. In addition, Islamic banks generally have good management skills compared to conventional banks. Earning Islamic branches of conventional banks are superior to full-fledge Islamic banks and conventional banks. Finally, we can conclude that Islamic banks have a configuration development.

Ahmed, Akhtar, and Usman (2011) found out in their study the factors in the company that have a significant impact on the risk management practices of Islamic banks in Pakistan. In their study they used credit, operational and liquidity risks as dependent variables, while the debt ratio, the size, N PL, capital adequacy and asset management are used as an explanatory variable and they took four-year period from 2006 to 2009. They resulted that size of Islamic banks have a positive and statistically significant relationship with financial risks (credit and liquidity risk), while its relation with operational risk is found to be negative and insignificant. The debt equity ratio and N PLs ratio have a negative and significant relationship with liquidity and operational risk. Capital adequacy has negative and significant relationship with credit and operational risk, while it is found to be positive and with liquidity risk.

Hassan and Bashir (2001) analyzed how bank individuality and the overall financial surroundings affect the presentation of Islamic banks. They used worldwide bank level date from 1994 to 2001 . They took variety of internal and external factors to examine the profitability and efficiency of the banks. For this purpose, they used the regression model to get the best results. They concluded that implicit and explicit taxes have negatively affected the bank's performance measures while favorable macroeconomic conditions have positively impact performance measures.

Javaid, Anwar, Zaman, and Gafoor (January 2011) analyzed the factors of profitability of ten banks working in 
Pakistan from 2004 to 2008. According to their research, they just focused on the internal factors. They took the assets, loans, equity, and deposits on one of the major profitability indicator return on asset (ROA) as an independent variable and used the pooled Ordinary Least Square (POLS) method to examine the impact of all independent variables with dependant variable. They concluded that independent variables have a strong control on the profitability. They also concluded that higher loans contribute towards profitability but their impact is not significant. Equity and Deposits have significant impact on profitability.

Gul, Irshad and Zaman (March 2011) observed the involvement between bank-specific and macro-economic uniqueness over bank profitability. They used data of top fifteen commercial banks of Pakistan from 2005 to 2009 . They applied pooled Ordinary Least Square (POLS) method. They took assets, loans, equity, deposits, economic growth, inflation and market capitalization as independent variables. They concluded that all factors have significant impact on profitability of banking in Pakistan.

Ali, Akhtar, and Ahmed (April 2011) studied to observe the profitability factors of public and private commercial banks working in Pakistan. They used independent variables, which were Return on Assets ROA and Return on Equity ROE. The descriptive, correlation and regression model were applied and results were derived with the help of SPSS. They concluded that there is a positive and significant relationship between dependant and independent variables.

Abdulraheem, Yahaya, and Aliu (2011) used the sample of first and second generation banks of Nigeria to observe significant variables that may clarify the profitability of the banks. They took ten banks as sample sizes with ten year base data. Dividend Declared, Amount Retained for Expansion, New Shares Sold out to the Public, Age of Banks, Customer Base and shareholders fund have been taken as independent variables. They applied multiple regression analysis. They resulted that the banks' performance was accounted for by the amount of profit paid out as dividend and Age of banks was shown not to be related to the banks' performance. They recommended based on their studies that Nigerian Banks should redirect their focus to early dividend payment and regular declaration of dividend as one of the tools of attaining better performance.

Bilal, Ahmed, and Khan (September 2012) took the internal factors which significantly impact the profitability of domestic banks in Pakistan. Return on Asset Ratio has been taken as dependant variable, whereas Cost to Income Ratio, Liquid Assets to Short Term Funding, Liquid Assets to Customers, Loan Loss Reserves to Gross Loans Ratio and EQAS have been taken as independent Variables. They applied Hausman Test on panel data regression of random effects over ten year's data from 2001 to 2010. The results indicated that the costs and EQAS LOSRES are statistically significant as independent variables and negatively related to ROA, and the results of these variables are based on expected signs. The LIQ variable is also a function of the expected sign and had negatively associated with ROA, but it is not statistically significant.

Faisal Khan (2011) conducted a study to identify the main determinants of bank profitability considering the variables specific bank. He took the data 16 banks on the basis of data from 2000 to 2010 . He used fixed effects model and random effects model to examine the impact of the net interest margin, the profit ratio 'bank size, loan growth, interest-free gain, overhead, taxes, insider loans, operating expenses, non-performing loans, return on assets ratio and deposition rate assets, and concluded that the non-performing loans are severely reduce the profitability of banks in small banks. 


\section{METHODOLOGY}

There are two types of data, primary and secondary data. But in this research, secondary data were taken. Secondary data were collected from newspaper articles and annual reports of banks. The annual financial information extracted from the web site selected financial institution. As the annual accounts and 1 - Average annual KIBOR. Sample size is ten years from 2002-2011. Before 2002, the banking sector has used PKRV rates instead of KIBOR. Once the changes in the reference rate, banks starting KIBOR rate as a benchmark to determine profitability. Pakistan five major banks selected from the total population of the banking sector 45 . Five banks are selected on the basis of total assets for the year ended December 31, 2011.

There are two types of variables i.e. dependent and independent, so I took interest income as a dependent variable income earned on earning assets. Such as deposits with other banks, which lend to financial institutions, investments and loans and advances to the interest rate effect are independent variables. Interest rates: in simple terms is the cost of borrowing. In this research a rate KIBOR year average used for analysis. Balances with other banks - deposit accounts: the excess liquidity of banks held with the different financial institution in order to earn profit. These investments have no fixed maturity period. Loans to financial institutions are places of Bank of surplus funds with different banks profits. These courses have fixed maturity period. Investment: is defined as the bank to purchase certificates of the issuer by providing financial assistance. When the borrower to repay the bank loan funds and then sell the certificate to the borrower. Loans and advances are defined as funds allow the customer to fulfill their commitment and obligations.

According to the objectivity of the study, the following hypothesis developed through research to profitability is the dependent variable against the independent variables, which include internal and external factors that may affect profitability. Following hypothesis is taken:

H1: There is significant relationship between advances, deposits, interest income, interest rate, investment with the profitability of the banks

The data were taken from the analysis of the report published by the State Bank of Pakistan. All figures in the data are in Pakistani rupees. We have various determinants that affect the profitability of banks. The data were analyzed using a regression model to learn the relationship between the dependent and independent variables.

InI $=\alpha+b 1$ IR + b2BWOB + b3LF $+b 4 I N V+b 5 L A$

- $\quad \mathrm{InI}=$ Interest Income

- $\quad \mathrm{IR}=$ Interest Rate

- $\mathrm{BWOB}=$ Balances with other banks - deposit accounts

- $\quad \mathrm{LF}=$ Lending to Financial Institution

- $\quad \mathrm{INV}=$ Investments

- $\quad \mathrm{LA}=$ Loan \& Advances

\section{Data Analysis and Finding}

Data analysis and findings are based on the statistical analysis. The basic criterion involved in regressing the 
dependent variable (cost) against the independent variables are advance (loans), deposits (liabilities), interest, balance with other banks, loans to financial institutions. This provided a test of the relationship between the dependent variable and the independent variables and, therefore, the following regression was adopted.

This table displays $\mathrm{R}, \mathrm{R}$ squared, adjusted $\mathrm{R}$ squared and the standard error. $\mathrm{R}$ is the multiple correlation coefficient, is the relationship between the independent variables and dependant variable. Here, we have value of R 0.523. This indicates that there is good relationship. $\mathrm{R}$ squared is the proportion of variation in the dependant variable explained by the independent variables. $\mathrm{R}$ squared value is 0.274 or 27 percent. This indicates that 27 percent variation in the dependant variable explained by the independent variable and remaining un-explained. Adjusted $\mathrm{R}$ squared attempts to correct R squared to more closely reflect the goodness of fit of the model. Here, standard error of the estimate is considerably lower as compare to standard deviation.

Table: Model Summary ${ }^{\mathbf{b}}$

\begin{tabular}{|c|c|c|c|c|c|c|c|}
\hline \multirow[b]{2}{*}{ Model } & \multirow[b]{2}{*}{$\mathbf{R}$} & \multirow[b]{2}{*}{$\begin{array}{c}\mathbf{R} \\
\text { Square }\end{array}$} & \multirow[b]{2}{*}{$\begin{array}{l}\text { Adjusted } \\
\text { R Square }\end{array}$} & \multirow{2}{*}{$\begin{array}{l}\text { Std. Error } \\
\text { of the } \\
\text { Estimate }\end{array}$} & \multicolumn{2}{|c|}{ Change Statistics } & \multirow[b]{2}{*}{$\begin{array}{c}\text { Sig. F } \\
\text { Change }\end{array}$} \\
\hline & & & & & $\begin{array}{l}\text { R Square } \\
\text { Change }\end{array}$ & $\begin{array}{c}\text { F } \\
\text { Change }\end{array}$ & \\
\hline 1 & $.523^{\mathrm{a}}$ & .274 & .191 & 948.130 & .274 & 3.314 & .013 \\
\hline \multicolumn{8}{|c|}{$\begin{array}{l}\text { a. Predictors: (Constant), LA, INV, LTFI, BWOB, } \\
\text { KIBOR }\end{array}$} \\
\hline b. Depe & $\operatorname{dent} \mathrm{V}$ & riable: IN & & & & & \\
\hline
\end{tabular}

Table: ANOVA ${ }^{\mathrm{b}}$

\begin{tabular}{|c|c|c|c|c|c|c|}
\hline \multicolumn{2}{|c|}{ Model } & Sum of Squares & Df & Mean Square & F & Sig. \\
\hline \multirow{5}{*}{1} & Regression & $1.490 \mathrm{E} 7$ & 5 & 2979069.755 & 3.314 & $.013^{\mathrm{a}}$ \\
\cline { 2 - 7 } & Residual & $3.955 \mathrm{E} 7$ & 44 & 898950.350 & & \\
\cline { 2 - 7 } & Total & $\mathbf{5 . 4 4 5 E 7}$ & $\mathbf{4 9}$ & & & \\
\hline \multicolumn{2}{|l|}{ a. Predictors: (Constant), LA, INV, LTFI, BWOB, KIBOR } & & \\
\hline \multicolumn{2}{|l|}{ b. Dependent Variable: INI } \\
\hline
\end{tabular}

ANOVA table shows fitness of model. 013 value of significant is less than 0.05 which shows that independent variables do a good job explaining the variation in the dependent variable.

\section{Coefficients $^{\mathrm{a}}$}

\begin{tabular}{|c|c|c|c|c|c|c|c|c|}
\hline & \multirow{2}{*}{ Model } & \multicolumn{2}{|c|}{$\begin{array}{l}\text { Un standardized } \\
\text { Coefficients }\end{array}$} & \multirow{2}{*}{$\begin{array}{c}\begin{array}{c}\text { Standardized } \\
\text { Coefficients }\end{array} \\
\text { Beta }\end{array}$} & \multirow{2}{*}{$\mathbf{t}$} & \multirow{2}{*}{ Sig. } & \multicolumn{2}{|c|}{$\begin{array}{l}\text { Co linearity } \\
\text { Statistics }\end{array}$} \\
\hline & & B & $\begin{array}{c}\text { Std. } \\
\text { Error }\end{array}$ & & & & Tolerance & VIF \\
\hline \multirow{6}{*}{1} & (Constant) & -698.99 & 550.83 & & -1.269 & .211 & & \\
\hline & KIBOR & -.299 & .126 & -.248 & -1.730 & .041 & .801 & 1.248 \\
\hline & BWOB & -.262 & .118 & -.306 & -2.219 & .032 & .871 & 1.149 \\
\hline & LTFI & .226 & .790 & .039 & .286 & .776 & .892 & 1.122 \\
\hline & INV & -.035 & .118 & -.039 & -.293 & .771 & .942 & 1.062 \\
\hline & LA & .217 & .083 & .389 & 2.631 & .012 & .755 & 1.324 \\
\hline
\end{tabular}

Coefficient table describes the relationship between each of the independent variables and the dependent variable. A positive coefficient of an independent variable means that when that variable increase by 1 unit, on average the dependent variable will increase by the amount of the coefficient (holding all the other variables constant). If the coefficient is negative, an increase of 1 unit in the independent variable will result in a decrease by the amount equal to the 
coefficient in the dependent variable (holding all the other variables constant). In this model Beta value shows KIBOR, Balance with Other Bank (BWOB) and Investment (INV) have significant impact on dependent variable.

\section{CONCLUSIONS}

The objective of this research is to evaluate the impact of changes in interest rates on bank profitability. Bank interest income is strongly influenced by the interest rate, investment and loans and advances. Regression technique also shows these results. This means that the profitability of banks depends on the interest rate, which is the tool of monetary policy. Interest income, investments and loans and advances are significantly related to interest rates. Interest income is strongly associated with interest rates.

More specifically, in the context of higher interest rates, higher interest rates usually greater than the increase in deposit rates, which results in pushing up the bank spreads. On the other hand, in a scenario of lower interest rates, the risk facing arrive. When increases in interest rates, lending rates tend to adapt more quickly compared to deposit rates. In a situation of declining deposit rates adjust faster than lending rates.

It is feared that further increase in interest rates will dampen growth in advances and increase in bad debts. Load up capital requirement of Rs. 7 billion until 2010 by the SBP also encourage further consolidation in the banking sector. He used to lessen the impact of risk, conservative growth in deposits and advances, bringing lower rate advances deposits. But, the main concern is the movement of interest rates in much damage. It will be very difficult for anyone to save money and make investments in the economy.

\section{RECOMMENDATIONS}

Banks can reduce their risk without the involvement of money, developing their attention to the interest not. Banks must take steps to realize capital adequacy ratio and sudden changes in interest rates. The central bank should play their role in the normalization of the interest margin.

There was a difference of 5 to 8 percent between what banks in Pakistan have paid the deposit holders and what they were charging borrowers, which does not conform to the international level. Bank management should logically focus on improving the quality of banks' profitability by providing better returns for depositors and request the lower rate of interest to borrowers for the development of the economy.

\section{REFERENCES}

1. Abbas, F., Tahir, M., \& Rehman, M. u. (2012). A Comparison of Financial Performance in the Banking Sector. Journal of Business Administration and Education, Vol 1,No 1, 1-14.

2. Abdulraheem, A., Yahaya, K. A., \& Aliu, O. A. (2011). Determinants of Performance: As Cross Generational Analysis of. European Journal of Social Sciences, Volume 24, Number 4, 458-465.

3. Ahmed, N., Akhtar, M. F., \& Usman, M. (2011). Risk Management Practices and Islamic Banks:An Empirical Investigation from Pakistan. Interdisciplinary Journal of Research in Business, Vol. 1, Issue. 6,, 50-57.

4. Akhtar, M. F. (2011). Liquidity Risk Management A comparative study between Conventional and Islamic Banks of Pakistan. Interdisciplinary Journal of Research in Business, 1(1), 35-44.

5. Akhtar, M. F., Ali, K., \& Sadaqat, S. (2011). Factors Influencing the Profitability of. International Research Journal of Finance and Economics. 
6. Ali, K., Akhtar, M. F., \& Ahmed, P. Z. (April 2011). Bank-Specific and Macroeconomic Indicators of Profitability - Empirical Evidence from the Commercial Banks of Pakistan. International Journal of Business and Social Science, Vol. 2 No. 6, 235242.

7. Syed Moudud-Ul-Huq \& Panuel Rozario Prince, Practice of Human Resource Accounting in Banking Sector of Bangladesh, International Journal of Accounting and Financial Management Research (IJAFMR), Volume 2, Issue 2, May - June 2012, pp. 14-23

8. Asghar, M. J., Mushtaq, N., \& Mirza, H. H. (MARCH 2012). Factors Influencing The Profitability Of Leasing Firms In Pakistan. SS International Journal of Business and Managment Research, VOLUME 2, ISSUE 2.

9. Azam, M., \& Siddiqui, S. (2012). Domestic and Foreign Banks' Profitability. International Journal of Economics and Financial Issues, Vol. 2, No. 1,, 33-40.

10. Bilal, N., Ahmed, S., \& Khan, Z. A. (September 2012). DETERMINANTS OF PROFITABILITY OF PAKISTANI BANKS. Journal Of Business Study Quarterly, Vol. 4, No. 1, 149-165.

11. Bukhari, s. A., \& Qudous, R. A. (2012). Internal and External Determinants of Profitability of Banks. Interdisciplinary Journal of Contemporary Reasearch in Business, VOL 3, NO 9, 1043.

12. Gul, S., Irshad, F., \& Zaman, K. (March 2011). Factors Affecting Bank Profitability In pakistan. The Romanian Economic Journal, 61-87.

13. Hassan, M. K., \& Bashir, A.-H. M. (2001). Determinants of Islamic Banking Profitability. ERF Paper.

14. Javaid, S., Anwar, J., Zaman, K., \& Gafoor, A. (January 2011). Determinants of Bank Profitability in Pakistan: Internal Factor Analysis. Mediterranean Journal of Social Sciences, Vol. 2, No. 1.

15. Khan, F., Anuar, M. A., Choo, L. G., \& Khan, H. (2011). Determinants of Bank Profitability in Pakistan. World Applied Sciences Journal 15 (10), 1484-1493.

16. Kouser, R., \& Saba, I. (2012). Gauging the Financial Performance of Banking Sector. International Research Journal of Finance and Economics ISSN 1450-2887 Issue 82.

17. Kutsienyo, a. (May 2011). The Determinant of Profitability of Banks in Ghana.

18. Rahman, S. u., jan, D. F., Iqbal, K., \& Ali, Z. (2012). Parameters of conventional and Islamic Bank's profitability in Pakistan. Research Journal of Finance and Accounting ISSN 2222-1697, Vol 3, No 3.

19. Saklain, M. S. (May 2012). The Profitability determinants of Private Commercial Bnaks in Bangladesh.

20. Zeitun, R. (March 2012). Determinants of Islamic and Conventional Banks Performance in GCC Countries Using Panel Data Analysis. Global Economy a nd Finance Journal, Vol. 5. No. 1., 53 - 72. 
